Jurnal Abdimas Berdaya : Jurnal Pembelajaran, Pemberdayaan dan Pengabdian Masyarakat Volume 4 Nomor 02 Tahun 2021

P-ISSN: $2685-1563$ e-ISSN: 2720 - 9768

\title{
Pengenalan Daya Tarik Wisata Kampung Batu Malakasari Bagi Siswa-Siswi SMK Jakarta Wisata I Jakarta Selatan
}

\section{Introduction to Tourism Attractions of Kampung Batu Malakasari for Students of SMK Jakarta Wisata I, South Jakarta}

\author{
Juliana $^{1)}$, Nova Bernedeta Sitorus ${ }^{2)}$, Yustisia Kristiana ${ }^{3)}$, Jessica Ardania ${ }^{4)}$, \\ Natalie $^{5}$ \\ 1,3,4,5 Universitas Pelita Harapan, Indonesia \\ 2.Universitas Pradita, Indonesia \\ e-mail: 1juliana.stpph@uph.edu, ${ }^{2}$ novairene579@gmail.com, \\ 3yustisia.kristiana@uph.edu, ${ }^{4}$ A70021@ @student.uph.edu, ${ }^{5}$ A70025@ student.uph.edu
}

\begin{abstract}
Abstrak: Obyek wisata merupakan sesuatu wujud sarana yang bisa menarik turis ataupun wisatawan buat tiba ke zona ataupun tempat tertentu. Ini pula identik dengan aksi seorang berangkat ke sesuatu tempat. Dedikasi kepada warga ialah salah satu tri dharma akademi besar yang bisa bertujuan buat menghadirkan serta membagikan modul serta pengetahuan seputar pertumbuhan pariwisata dikala ini. Dedikasi kepada warga ini dicoba secara online lewat aplikasi zoom meeting. Dengan diadakannya workshop pengenalan pengetahuan pertumbuhan pariwisata dikala ini spesialnya energi tarik wisata diharapkan partisipan bisa memahaminya. Partisipan dalam aktivitas ini merupakan siswa- siswi Sekolah Menengah Kejuruan Jakarta Wisata I yang berlokasi di Jakarta Selatan. Hasil aktivitas dari dedikasi kepada warga ini sangat menunjang partisipan buat lebih memahami energi tarik wisata di Kampung Batu Malakasari dijadikan selaku bekal buat mengenali pertumbuhan pariwisata yang terdapat yang terdapat di Kabupaten Bandung.
\end{abstract}

Kata Kunci: Daya Tarik Wisata, Kampung Batu Malakasari, Pengabdian Kepada Masyarakat.

Abstract: A tourist attraction is a form of facility that can attract tourists or tourists to come to a certain area or place. This is also synonymous with the action of a person going to a place. Dedication to residents is one of the three major academic dharmas that can aim to present and share modules and knowledge about the current development of tourism. This dedication to residents is tried online through the Zoom Meeting application. By holding a workshop to introduce knowledge about tourism growth at this time, especially tourist attraction, it is hoped that participants can understand it. The participants in this activity are students of the Jakarta Wisata I Vocational High School located in South Jakarta. The results of this activity from dedication to residents really support participants to better understand the tourist attraction in Batu Malakasari Village as a provision to recognize the growth of tourism in Bandung Regency.

Keywords: Tourist Attraction, Kampung Batu Malakasari, Community Service

\section{A. Pendahuluan}

Dalam lingkungan yang dinamis dan global saat ini, tourism destination menghadapi kompetisi yang ketat karena banyak tujuan menyajikan atraksi yang sama 
Sebagai salah satu sektor ekonomi terbesar di dunia, travel dan tourism menciptakan lapangan kerja, dorongan dalam mengekspor dan menghasilkan kemakmuran di seluruh dunia. Perserikatan Bangsa-Bangsa menetapkan tahun 2017 sebagai Tahun Pembangunan Pariwisata Berkelanjutan Internasional (UNESCO, 2018) Tahun internasional ini memberikan kesempatan yang sangat besar untuk menampilkan nilai ekonomi, sosial budaya, lingkungan dan warisan luar biasa yang dapat dibawa oleh sektor ini.

Menurut (Weidenfeld, 2010) atraksi utama memiliki tingkat ikonik yang tinggi maupun rendah dapat hilang atau diperoleh seiring dengan waktu bergantung kepada faktor-faktor seperti kualitas produk pariwisata, kepadatan berlebih dan penurunan kualitas dan pesaing baru. Berdasarkan data dari kementerian pariwisata dan (Badan Pusat Statistik, 2019) pendapatan devisa Indonesia dari Sektor Pariwisata kunjungan wisatawan mancanegara maupun wisatawan nusantara terus meningkat setiap tahunnya. Pertumbuhan kunjungan wisatawan nusantara dan mancanegara tersebut dipaparkan melalui diagram batang dibawah ini

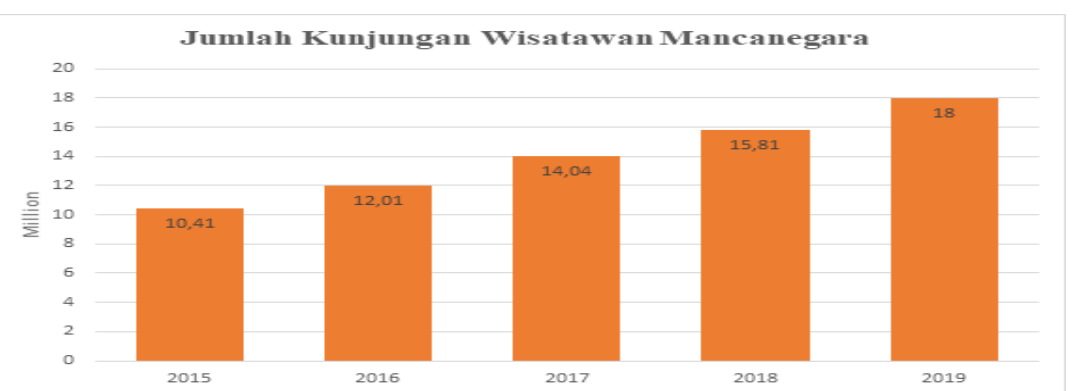

Gambar 1. Jumlah Kunjungan Wisatawan Mancanegara (2015-2019)

Sumber : kementerian pariwisata dan Badan Pusat Statistik (2019).

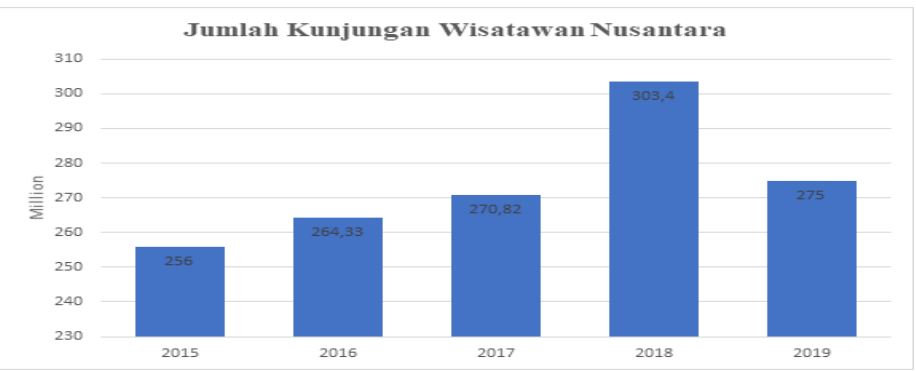

Gambar 2. Jumlah Kunjungan Wisatawan Nusantara (2015-2019)

Sumber : kementerian pariwisata dan Badan Pusat Statistik (2019).

Menurut Undang-Undang Republik Indonesia No. 10 Tahun 2009 tentang kepariwisataan, komponen yang terkait di dalam pariwisata adalah daya tarik wisata, aksesibilitas, fasilitas umum, fasilitas pariwisata, serta masyarakat yang terkait maupun layanan yang mendukung pariwisata itu sendiri. Menurut Cooper et al., (2014);Fletcher et al., (2017) pariwisata memiliki empat komponen penting, yaitu: attractions, 
accessibilities, amenities, ancillary services. Daya tarik mengacu pada suatu tempat atau apapun yang menarik bagi wisatawan untuk mengunjungi suatu destinasi (Suanmali, 2014). Tempat wisata termasuk wisata alam, atraksi budaya, dan rekreasi dan aktivitas. Atraksi tersebut antara lain atraksi alam seperti pemandangan gunung dan lembah, pemandangan alam dan atraksi alam, taman dan mata air, jalan setapak yang indah, taman, danau, sungai, margasatwa, gua, dan formasi bawah tanah. Bentuk lain dari atraksi hiburan dan acara, yang meliputi pertunjukan, pameran, acara dan festival budaya, musik barat dan kehidupan malam dan hiburan; serta tempat wisata bersejarah seperti sejarah, peninggalan, dan bangunan vintage (Rajesh, 2014). Tempat-tempat wisata ditemukan sebagai penentu inti dari daya tarik dan pariwisata tidak akan ada tanpanya (Haneef et al., 2019). Tempat wisata dianggap sebagai senjata esensial dan keunggulan kompetitif untuk tujuan wisata mana pun (Nahar et al., 2015). Tambahan lagi, (Manhas et al., 2016) juga menyatakan bahwa daya tarik wisata memberikan kontribusi terhadap perkembangan destinasi wisata serta memiliki pengaruh yang menguntungkan pada perkembangan ekonomi secara keseluruhan di negara mana pun. Atraksi juga merupakan atribut penting pariwisata dan perhotelan (Handayani, 2016).

Menurut situs resmi (Kampung Batu Malakasari, 2017) pada awalnya Kampung Batu Malakasari adalah sebuah kawasan penambangan batu alam yang pernah di eksploitasi secara tradisional oleh masyarakat setempat sejak tahun 1900-an. Kampung Batu Malakasari secara alamiah memiliki formasi geologi yang terdiri dari lapisan batuan dengan kesamaan karakteristik seperti jenis batu, fasies dan lain sebagainya yang dilengkapi dengan danau air tawar juga rimbunan pohon, yang membuat tempat ini menjadi lapisan bawah tanah yang mengandung air dan dapat mengalirkan air (akuifer) alami bagi lingkungan. Kampung Batu Malakasari memiliki luas 50.000m2 yang berlokasi di Jalan Raya Banjaran (Rencong), Desa Malakasari Kecamatan Baleendah, Kabupaten Bandung Jawa Barat. Kampung Batu Malakasari dulunya adalah untuk menambang batu alam yang secara tradisional telah dimanfaatkan oleh masyarakat daerah sejak tahun 1900. Di tahun 2002 dilakukan renovasi perbaikan kawasan Kampung Batu Malakasari yaitu seperti menimbun tanah dan bebatuan (reklamasi) hingga membentuk landscape wisata alam baru seperti Geowisata yang indah dan menarik oleh prakarsa Ir. Waryo yang merupakan pemilik lokasi, dibantu dengan ahli geofisika Ir. Bambang.

Selain sebagai wisata yang dengan konsep GeoWisata, Kampung Batu Malakasari juga dapat disebut sebagai kawasan Ekowisata yang sangat besar karena memiliki lahan hijau yang terbuka dengan luas hingga 70\%. Disisi lain, Kampung Batu Malakasari mempunyai danau sebagai icon wisata yang dapat memuat hingga puluhan ribu kubik air, dan juga memiliki kolam yang indah dan area persawahan. Keindahan danau buatan ini, dirawat dan diperindah oleh masyarakat setempat seperti ditanami bermacam jenis tanaman dan pohon di sekitarnya yang terbilang tanaman yang sangat langka, seperti apel beludru atau bisbul, Sawo Walanda, Sawo Durian. Selain itu ada terdapat juga tanaman pada umumnya seperti cemara, pohon kelapa, kelengkeng dan jambu air. 
Berikut merupakan aktivitas wisata yang dapat dilakukan oleh wisatawan dengan berbagai pilihan wahana wisata yang ada di Kampung Batu Malakasari : wisata kampung batu malakasari, wahana flying fox, wahana outbound kids, wahana arena adventure, wahana rumah pohon, wahana peternakan, wahana persawahan, wahana perkebunan, wahana budaya, Untuk dapat sampai ke Kampung Batu Malakasari, pengunjung dapat melewati jalan Cisangkuy ke arah barat daya menuju ke Ranca Bungur, setelah itu pengunjung memasuki Desa Malakasari. Apabila dari arah Banjaran, pengunjung hanya berjalan lurus hingga menemui petunjuk yang ada di pinggir jalan menuju Kampung Batu Malakasari. Berdasarkan uraian sebelumnya, penulis ingin berkontribusi dalam perkembangan pariwisata melalui memberikan informasi mengenai daya tarik wisata Kampung Batu Malakasari. Sesuai dengan lokasi yang dibahas maka penulis memutuskan untuk membuat sebuah buku mengenai daya tarik wisata Kampung Batu Malakasari. Disamping pembuatan buku, penulis juga ingin memberikan kontribusi bagi masyarakat terkhusus bagi siswa - siswi sekolah menengah kejuruan di bidang pariwisata melalui pengabdian kepada masyarakat melalui online Program Studi Usaha Perjalanan Wisata Universitas Pelita Harapan ingin memberikan pengenalan tentang daya tarik wisata Kampung Batu Malakasari, juga untuk mengetahui perkembangan pariwisata. SMK Jakarta Wisata 1 juga perlu diberikan pembekalan karena sekolah ini belum pernah mendapatkan materi terkait pariwisata khususnya daya tarik wisata Kampung Batu Malakasari Untuk menjawab permasalahan yang diuraikan sebelumnya maka tim pengabdian kepada masyarakat ini melakukan sebuah kegiatan yang memperkenalkan dan memberikan materi tentang daya tarik wisata Kampung Batu Malakasari kepada siswa - siswi tingkat sekolah menengah kejuruan. Kegiatan ini akan didampingi oleh guru pendamping, dosen pembimbing, dan mahasiswa dari Program Studi Usaha Perjalanan Wisata Universitas Pelita Harapan. Mahasiswa bertanggung jawab untuk mempersiapkan materi tentang pengenalan daya tarik wisata Kampung Batu Malakasari. Materi yang akan diajarkan meliputi : Gambaran daya tarik wisata secara umum, Profil Kampung Batu Malakasari, Daya tarik wisata Kampung Batu Malakasari secara keseluruhan

\section{B. Metode}

Untuk menjawab permasalahan yang ada, pada tahapan pelaksanaan ini, hal yang dilakukan program studi Usaha Perjalanan Wisata Universitas Pelita Harapan adalah mencari sekolah yang membutuhkan sosialisasi, membuat proposal PkM, mempersiapkan materi, dan persiapan acara secara online melalui aplikasi zoom meeting. Setelah kegiatan selesai, peserta dan panitia akan mendapatkan sebuah sertifikat. Kegiatan Pengabdian Kepada Masyarakat berlangsung secara daring ataupun online. Peserta akan terlibat dalam kegiatan tanya jawab dari materi yang telah disampaikan. Evaluasi Kegiatan ini dilakukan dengan membuka sesi tanya jawab bagi siswa-siswi SMK Jakarta wisata 1 seputar materi yang telah disampaikan sedangkan evaluasi dengan panitia dilaksanakan setelah acara selesai dan yang menjadi bahan 105 
evaluasi dalam kegiatan ini adalah pembuatan kuesioner sehingga lebih efektif dalam menilai hasil yang didapatkan dari kegiatan ini.

\section{Hasil dan Pembahasan}

Dalam kegiatan ini peserta yang hadir sebanyak 23 peserta, kegiatan dimulai dengan tepat waktu dan pemberikan materi diberikan melalui power point. Penjelasan materi dikemas sesuai dengan kebutuhan siswa SMK Jakarta Wisata 1. Presentasi dilakukan dalam satu sesi sesuai dengan topik yang diberikan. Setelah penjelasan materi selesai, peserta diberikan waktu untuk melakukan sesi tanya jawab sesuai dengan topik yang disampaikan. Hasil yang diharapkan adalah siswa dapat mengetahui dan mengenal salah satu destinasi wisata yang memiliki konsep geopark seperti Kampung Batu Malaksari. Di akhir acara tim pelaksana memberikan apresiasi berupa sertifikat dan ucapan terima kasih atas partisipasi berupa ovo cash sebesar IDR.20.000 per orang kepada seluruh siswa dan guru pendamping yang terlibat dalam kegiatan ini. Hasil kegiatan berupa siswa mengenal mengenai destinasi wisata yang memiliki konsep geopark dan fungsi dari setiap wahana yang terdapat di dalam Kampung Batu malakasari. Peserta mengetahui gambaran mengenai berbagai jenis daya tarik wisata yang ada di dalam Kampung Batu malakasari serta terjalin hubungan silaturahmi antara Program Studi Usaha Perjalanan Wisata Universitas Pelita Harapan dengan pihak SMK Jakarta Wisata 1. Hasil ini diukur dari pengisian Pre-Test dan Post-Test berjumlah masing-masing 5 butir pertanyaan yang diisi oleh 18 peserta. Pertanyaan dari Pre-Test dan Post-Test dijawab dengan memberikan skala nomor $1-6$ dimana skala 1 merupakan sangat tidak setuju, skala 2 tidak setuju, skala 3 sedikit tidak setuju, skala 4 sedikit setuju, skala 5 setuju dan skala 6 sangat setuju. Hasil dari evaluasi akan di paparkan dalam bentuk grafik. Berikut pertanyaan dan hasil dari evaluasi tersebut PreTest

1. Pre-Test

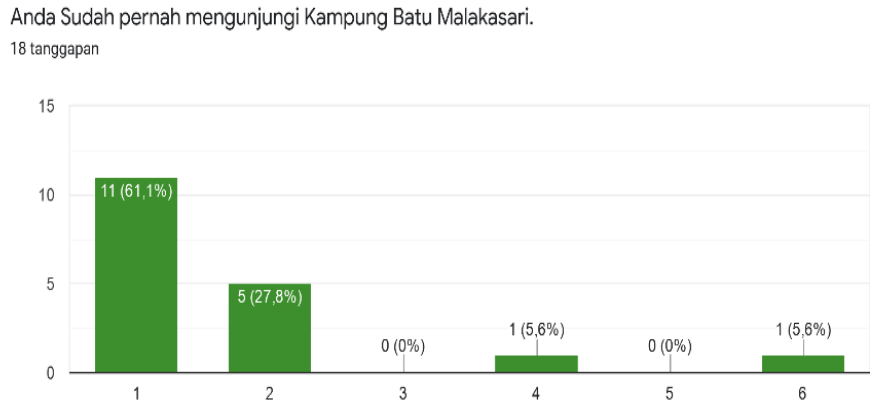

Gambar 3. Pertanyaan pertama

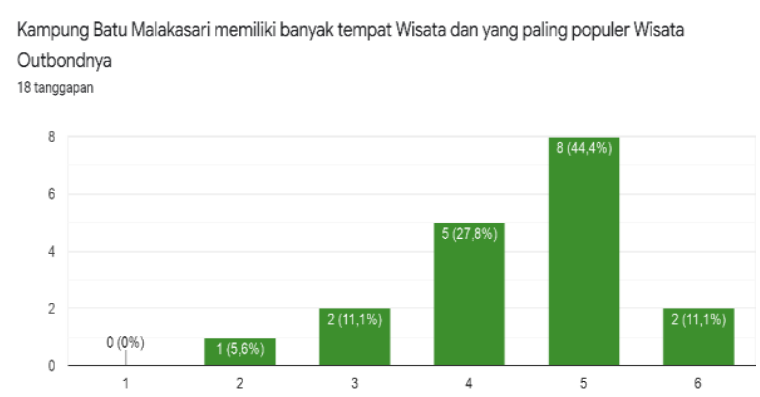

Gambar 4. Pertanyaan kedua 


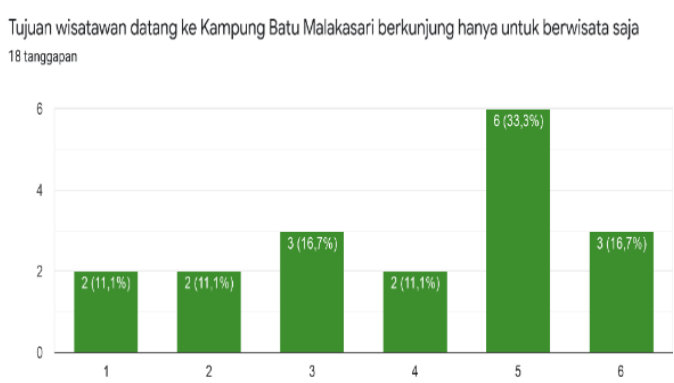

Gambar 5. Pertanyaan ketiga
Berbagai macam obyek wisata di Kampung Batu Malakasari memiliki daya tarik khas seperti wisata Outbond yang dapat menarik wisatawan

18 tanggapen

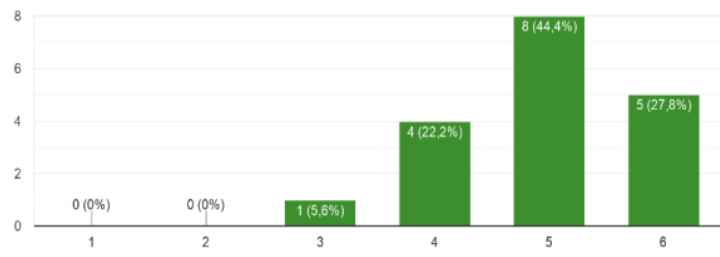

Gambar 6. Pertanyaan keempat

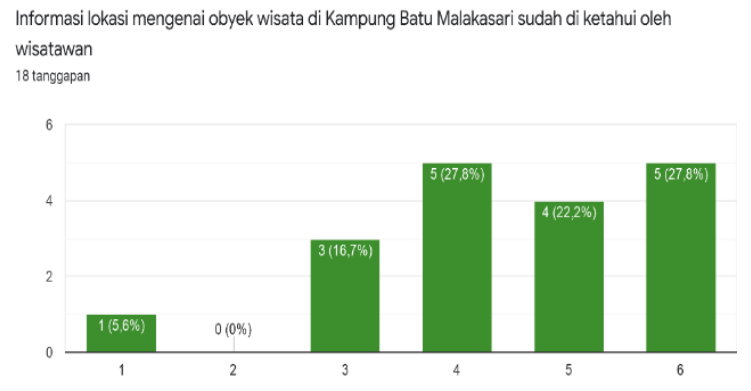

Gambar 7. Pertanyaan kelima

\section{Post-Test}

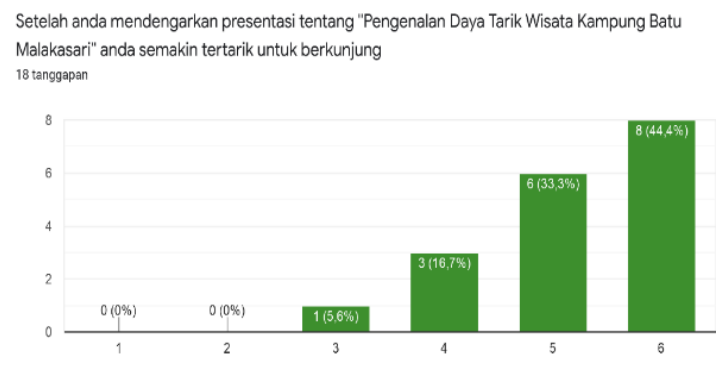

Gambar 8. Pertanyaan pertama

Setelah anda mendengarkan presentasi tentang "Pengenalan Daya Tarik Wisata Kampung Batu Malakasari" anda mendapatkan banyak informasi ....i obyek wisata tentang Kampung Batu Malakasari 18 targgapan

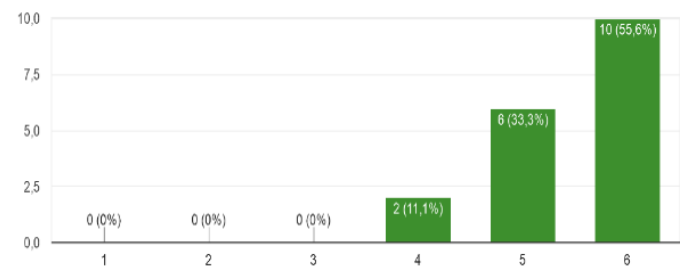

Gambar 10. Pertanyaan ketiga

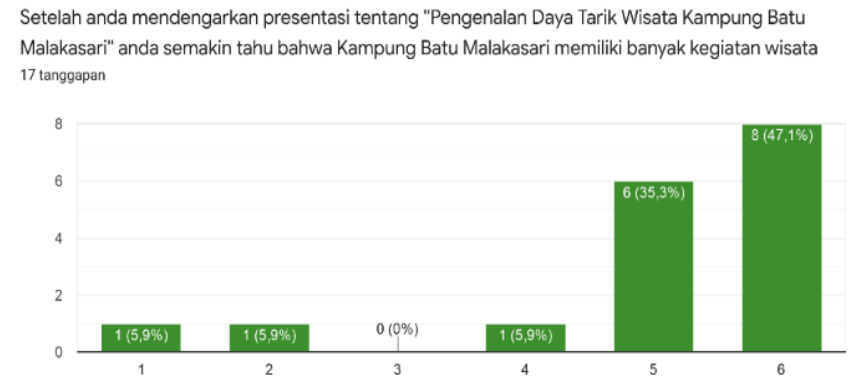

Gambar 9. Pertanyaan kedua

Setelah anda mendengarkan presentasi tentang "Pengenalan Daya Tarik Wisata Kampung Batu Malakasari" anda mulai mengetahui bahwa Kampung ...sari memiliki banyak sekali daya tarik wisatanya 18 tanggapan

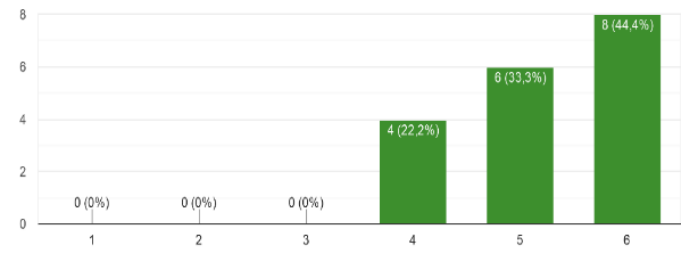

Gambar 11. Pertanyaan keempat 


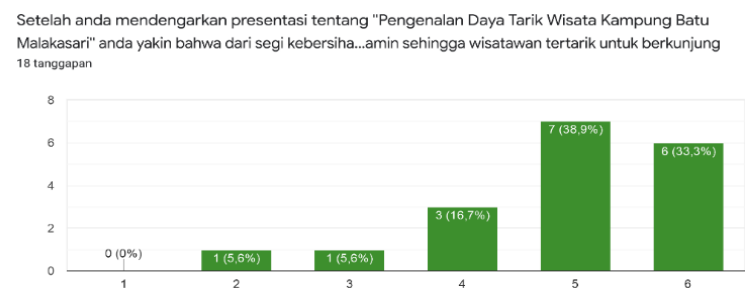

Gambar 12. Pertanyaan kelima

Dengan hasil Pre-Test dan Post-Test diatas, dapat disimpulkan bahwa peserta mendapatkan informasi mengenai gambaran berbagai jenis daya tarik wisata yang ada di dalam Kampung Batu malakasari dan Profil Kampung Batu Malakasari yang berarti peserta memahami materi-materi yang telah disampaikan oleh tim pelaksana.

\section{Simpulan}

Simpulan dari seluruh kegiatan ini adalah, pentingnya memberikan materi tentang pariwisata kepada pihak akademisi SMK Jakarta Wisata 1 sehingga dapat mendukung siswa untuk dapat lebih mengenal wisata yang ada di dalam Kampung Batu Malakasari. Dalam hal pemberian materi tentang pengenalan daya tarik wisata di Kampung Batu Malakasari dijadikan sebagai bekal untuk mengetahui perkembangan pariwisata yang ada yang ada di Kabupaten Bandung. Kegiatan ini sangat berguna untuk Program studi Usaha Perjalanan Wisata Universitas Pelita Harapan untuk menjalin kerjasama dengan sekolah-sekolah dalam membuat sebuah kegiatan pengabdian kepada masyarakat. Rekomendasi untuk kegiatan ini supaya tim pelaksana dapat memulai kegiatan dengan tepat waktu, dan dapat berpikir secara kritis dalam menjawab pertanyaan yang diberikan peserta dan selanjutnya kegiatan dapat ditambahkan dengan video pendukung atau video interaktif dan mengadakan pelatihan dengan offline agar penjelasan lebih mendalam.

Berikut dilampirkan foto dokumentasi kegiatan pengabdian kepada masyarakat
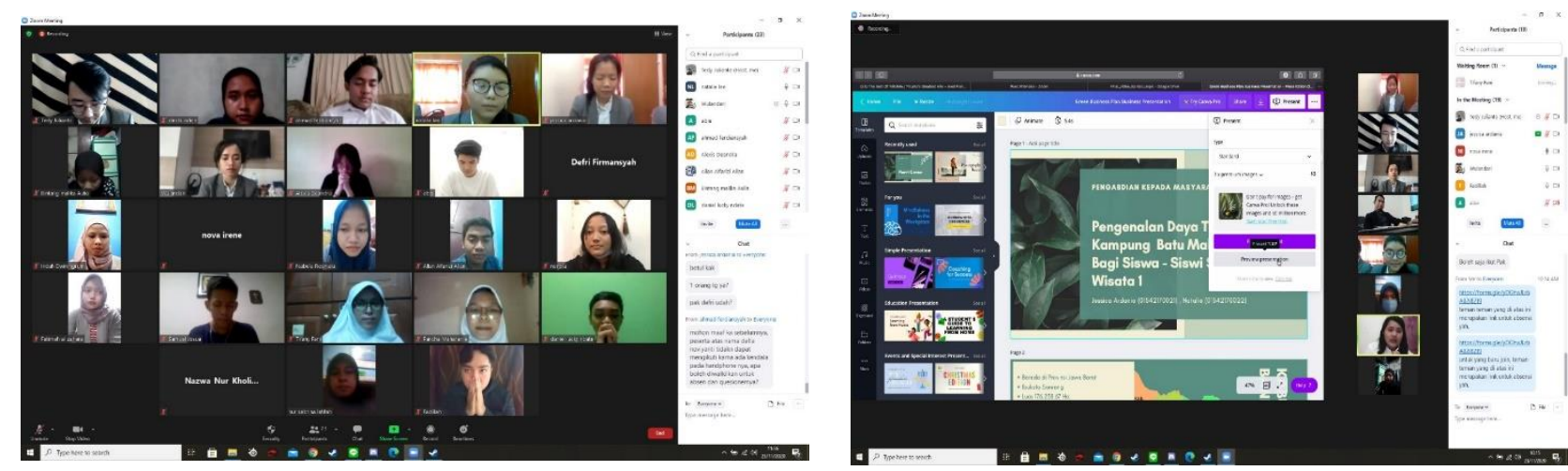

JURNAL ABDIMAS BERDAYA: Volume 4 Nomor 02 Tahun 2021 


\section{Acknowledgement}

Tim Pengabdian Kepada Masyarakat mengucapkan banyak terima kasih kepada LPPM UPH yang telah memberikan kesempatan melaksanakan kegi atan pengabdian kepada masyarakat (PM-148-M/FPar/X/2020).

\section{Daftar Rujukan}

Cooper, C., Flethcher, J., Fyall, A., Gilbert, D., and Wanhill, S. (2014). Tourism: Principles and Practice, 4th ed. London: Prentice Hall.

Fletcher, J., Fyall, A., Gilbert, D.\& Wanhill, S. (2017). Tourism:Principles and Practice, 6th Edition. United Kingdom: Pearson Education Limited.

Handayani, B. (2016). The influence of tourism and hospitality attributes on nationbrand image, national identity and behaviour intentions. Doctoral dissertation, Universiti Utara Malaysia, Kedah, Malaysia.

Haneef, S.K., Ansari, Z., \& Bhavani, G. (2019). Attractions of Dubai and Expo 2020: An exploratory study. Worldwide Hospitality and Tourism Themes, 11(3), 266278.

Malakasari, K. B. (2017). Retrieved sept 15, 2020, from http://kampungbatu.co.id/.

Manhas, P.S., Manrai, L.A., \& Manrai, A. K. (2016). Role of tourist destination development in building its brand image: A conceptual model. Journal of Economics, Finance and Administrative Science, 21(40), 25-29. https://doi.org/10.1016/j.jefas.2016.01.001.

Nahar, K., Islam, S.R., \& Rahman, K. (2015). Selection of a tourist attractions using AHP method: The case of Bangladesh. World Journal of Social Sciences, 5(3), 211-226.

Rajesh, R. (2014). Impact of tourist perceptions and satisfaction on destination loyalty: A case study of Puducherry tourism. Doctoral dissertation, Pondicherry University, Puducherry, India.

Statistik, B. P. (2019). Pendapatan Devisa Indonesia dari Sektor Pariwisata (20092019), Retrieved Sept 18, 2020, from https://databoks.katadata.co.id/datapublish/2018/09/10/berapa-pendapatandevisa-dari-sektor-pariwisata-indonesia.

Suanmali, S. (2014). Factors affecting tourist satisfaction: An empirical study in the northern part of Thailand. In SHS Web of Conferences (Vol. 12, p. 0102). EDP Sciences. https://doi:10.1051/shsconf/20141201027. 
UNESCO. (2018). UNESCO and the international year of sustainable tourism", available at: https://en. unesco.org/iyst4d.

Weidenfeld, A. (2010). Iconicity and 'flagshipness' of tourist attractions”, Annals of Tourism Research, Vol. 37 No. 3, pp. 851-854. 